\title{
Morphological Changes in the Midface of Beagle Dogs Treated by Trans-Sutural Distraction
}

\author{
Cambios Morfológicos en la Cara Media de Perros \\ Beagle Tratados por Distracción Trans-Sutural
}

Bin-Bin Zhang ${ }^{1 *}$; Rui Han ${ }^{1 *}$; Ya-Kun Liu ${ }^{1}$; Quan-Wen Gao ${ }^{2} \&{\text { Bing } \mathbf{~ L i}^{1}}^{1}$

\begin{tabular}{l}
\hline ZHANG, B. B.; HAN, R.; LIU, Y. K.; GAO, Q. W. \& LI, B. Morphological changes in the midface of beagle dogs treated by trans-sutural \\
distraction. Int. J. Morphol., 38(4):947-955, 2020.
\end{tabular}

SUMMARY: Trans-sutural distraction is a biological process that induces the formation of new bone and changes the position of bone by pulling on growing suture under the action of external forces. Currently, therapy to midfacial hypoplasia treated by trans-sutural distraction has been applied. In this study, Beagle dogs were selected as experimental animals, and a traction device designed by ourselves was applied to Beagle dogs to simulate the treatment process of trans-sutural distraction in human face, so as to provide a basis for the subsequent research on the related mechanism of trans-sutural distraction. The objective is that the animal model can provide the basis for the follow-up study of transsutural distraction. 45 month beagle dogs were randomly divided into two groups 3 in experiment group and 3 in control group. Implant nails were implanted as the bone marker in the bilateral zygomatic temporal suture, zygomandibular maxillary suture and palatine transverse suture in experimental group. The traction of the maxilla was carried out by the external cranial traction frame with canine fossa as bearing point, $800 \mathrm{~g}$ force each side, elastic traction for 15 days. The control group only implanted the implant nail as the bone marker on both sides of the bone suture. The distance between two implant nails was measured by vernier calipers and X-ray examination, compared with preoperative and postoperative changes. X-ray and cephalometric measurements were used to measure change in the cranial basal angle. HE staining was used to observe the width of the bone seams, the morphology and structure of the cells and the tissue of the new bone under the phase contrast microscope. Then descriptive statistical analysis and t-test between two independent samples are carried out for the measurement data. The experimental group had a good retention of the beagle traction frame. In the experimental group, the maxillaries of dogs were protrudent in the process of traction gradually and the occlusal relationship changed to type II malocclusion. When the traction is 15 days, the coverage distance is about $8 \sim 9$ $\mathrm{mm}$. Before and after the traction, the distance between landmark points indicated that the spacing between the transverse palatine suture was the largest (experimental group: $5.52 \pm 0.19 \mathrm{~mm}$ control group $1.31 \pm 0.06 \mathrm{~mm} P<0.05$ ), and zygomaticotemporal suture was the second (experimental group: $3.12 \pm 0.15 \mathrm{~mm}$, control group $0.73 \pm 0.04 \mathrm{~mm}, P<0.05$ ), and zygomaticomaxillary suture was less (experimental group: $2.60 \pm 0.34 \mathrm{~mm}$, control group $0.53 \pm 0.05 \mathrm{~mm}, P<0.05$ ). The cranial basal angle was no change before and after operation (controlgroup: $32.3 \pm 1.3^{\circ}$, experimental group: $33.2 \pm 1.1^{\circ} P>0.05$. Histology showed that the collagenous fibers in the suture of the control group were denser and the osteoblasts were visible on the edge of the suture, showing osteogenic activity. The experimental group significantly widened suture (experimental group: $1209.388 \pm 42.714 \mu \mathrm{m}$, control group $248.276 \pm 22.864 \mu \mathrm{m}, P<0.05)$, the number of fibroblasts increased significantly with loose collagen fiber. The direction of cell and fiber arrangement were parallel to the traction force. There were many small blood vessels and marrow cavities, and the bone trabecula around the bone suture was thin (experimental group: $23.684 \pm 3.774 \mathrm{~mm}$, control group: $86.810 \pm 9.219 \mathrm{~mm}, P<0.05$ ), showing active osteogenic activity. The growing beagle dog can be used to establish a suture traction animal model for experimental study. In the experiment, Kirschner wire was used to penetrate the bottom plane of the piriform hole of the maxilla (about the position of the canine fossa at the back) and the traction direction was basically the same as the growth direction, and the maxilla was basically parallel and moved forward.

KEY WORDS: Suture diatraction osteogenesis; Extracranial traction frame; Midfacial hypoplasia; animal model.

\section{INTRODUCTION}

Midfacial hypoplasia is a common disease in maxillofacial surgery. Its clinical features include the hypoplasia of maxilla in three-dimensional direction, midfacial concave deformity, class III malocclusion of angle's, which leads to the maladjustment of patients' facial morphology and oral and maxillofacial functions, and

\footnotetext{
${ }^{1}$ Department of Prosthodontics, School of Dentistry, Shanxi Medical University, Taiyuan, China.

${ }^{2}$ Department of Burns and Plastic Surgery, First Hospital Affiliated to General Hospital of PLA, Beijing, China.

Bin-Bin Zhang and Rui Han: Both authors contributed equally to this work.

FUNDING: Beijing Natural Science Foundation of China, No. 7144249.

The Institutes Foundation of Hospital of Stomatology Shanxi Medical University, No. KY201807.

The Cultivate Scientific Research Excellence Programs of Higher Education Institutions in Shanxi, No. 2019KJ024
} 
seriously affects their physical and mental health (Scolozzi, 2008). Genetic and environmental factors or acquired injuries during the early stage of life may lead to midfacial hypoplasia(Marulanda \& Murshed, 2018). Patients affected by clef lip and palate (CLP) are most susceptible to develop into midfacial hypoplasia (Lin et al., 2016). The common orthopaedic approach for mild to moderate midfacial hypoplasia in growing patients with CLP, is maxillary protraction with tooth-borne or bone-borne anchorage, and the latter gradually occupies the dominant position by virtue of the advantage of decreasing unwanted dentoalveolar effects while increasing skeletal effects (Yatabe et al., 2017; Garib et al., 2018). However, for a certain proportion of those with severe forms, maxillary protraction in either type cannot achieve adequate skeletal changes within less than $6 \mathrm{~mm}$ advancement of A-point according to current studies (Meazzini et al., 2019). With the development of orthodontic and orthognathic techniques, the technique of trans-sutural distraction osteogenesis (TSDO), which shares the same treatment principle with bone-anchored maxillary protraction using facemask, has just emerged to fill this gap, and has been applied in clinical practice (Tong et al., 2015). TSDO is a biological process that induces the formation of new bone and changes the position of bone by pulling on growing seams under the action of external forces and the forward displacement of the midface can be increased by 2-4 times under traction (Liu et al., 2005). At present, there are complications such as long treatment period and poor mineralization when new bone is formed about TSDO, which needs to be solved continuously to expand the application field of this technology.

The research focused in this field, is the mechanism of trans-sutural distraction and the improvement of traction osteogenesis efficiency, but there are few reports about the biological basis and related theories. In this study, Beagle dogs were selected as experimental animals, and the selfdesigned traction device was applied to beagle dogs to simulate the treatment process of TSDO of human midfacial hypoplasia. We hope to establish a reliable animal model of bone suture traction in the middle of the face, and provide the basis for the follow-up study of the mechanism of suture traction osteogenesis.

\section{MATERIAL AND METHOD}

This study was conducted in the experimental animal center of the First Affiliated Hospital of PLA General Hospital and the Basic Medical Research Institute of the PLA General Hospital from May 2016 to August 2018.
Experimental animals and groups. Beagle dogs (Beijing Maas Biotechnology Co, Ltd, license: SCXK 2016-0001); The beagle dogs were randomly divided into two groups: 3 in experiment groups (SDO) and 3 in control group(NC). Implant nails were implanted as the bone marker in the bilateral zygomatic temporal suture, zygomandibular maxillary suture and palatine transverse suture in experimental group. The traction of the maxilla was carried out by the external cranial traction frame with canine fossa as bearing point. The control group only implanted the implant nail as the bone marker on both sides of the bone suture.

Traction device, traction method and force measurement method. Include the traction of the cranial traction frame designed by ourselves, Kirschner wire with a diameter of $3.00 \mathrm{~mm}$ (Orthopedics department of the first affiliated hospital of PLA general hospital), and orthodontic rubber ring (Orthodontic department of the first affiliated hospital of PLA general hospital). The traction device was made by Beijing Jima Fei Technology Development Co., Ltd. The external traction frame imitates Martin firm external fixed traction device for clinical use, which is composed of head circle, vertical bar and horizontal bar. 16-week-old male beagle dogs were selected for head CT examination, and the head CT data was input into the 3D reconstruction software. The design was completed with PRO/E software, and the aluminum alloy traction frame was processed with $\mathrm{CNC}$ lathe. The fixing screws were made of ordinary stainless steel screws with a diameter of $4 \mathrm{~mm}$. The orthodontic rubber band was under continuous elastic traction with a force value of $800 \mathrm{~g}$ on each side, which was measured by orthodontic dynamometer. The total weight of the traction device is $150 \mathrm{~g}$.

\section{Suture distraction osteogenesis model establishment and} the basic operation. Beagle dogs in the experimental group were deprived of water and food for $24 \mathrm{~h}$ before surgery. Intravenous anesthesia (3\% pentobarbital sodium, $1 \mathrm{ml} / \mathrm{kg}$, Animal center of the first affiliated hospital of PLA general hospital), routine preparation of skin, disinfection of towel, surgical exposure of experimental bone seam, including the bilateral zygomatic temporal suture, zygomandibular maxillary suture and palatine transverse suture of both sides, the implant nail is implanted the bone seam on each side as a landmark, pulling up bilateral maxillary teeth. A $2 \mathrm{~mm}$ small incision in the skin of the canine fossa on both sides was made, and periosteum was peeled off. An electric drill to Pierce the Kirschner wire was used, with a diameter of 3 $\mathrm{mm}$ from the left fossa to the right. The $20 \mathrm{~mm}$ length was maintained on each side and excess parts were cut off. The external cranial traction frame was placed, and screws fixed on the frontal and parietal bones on both sides. After surgery, the orthodontic rubber band was used to continuously traction the middle of the face, with the traction force of $800 \mathrm{~g}$ on 
each side, and the traction plane was parallel to the palatal plane for about 15 days (Figs. 1A and 1B). In the control group, only implant nails on both sides of the bone seam were used as markers.

Nursing and feeding. All experimental animals were treated with antibiotics on the day of surgery and 3 days after surgery (sodium penicillin, intramuscular injection, $800,000 \mathrm{u}$, twice a day). Local wounds were disinfected daily with iodinovolt and rubber bands were replaced. Beagles were fed 3 times a day with high quality concentrate.

General observation. The eating and mental state of beagles were recorded, and the stability of the traction frame, the tolerance of Beagles and the traction effect were observed. The distance between the two screws was measured by Vernier caliper when the implant nail was implanted and the traction was completed (the error was $0.02 \mathrm{~mm}$ with the center of the implant nail as the measuring point). The stability of the traction frame, the tolerance of the beagle and the traction effect were observed. X-ray examination and comparison of skull X-ray before and after traction showed that the difference between implant nails in bone suture in the experimental group was different from that in the control group. The basic changes of skull base Angle were measured by head shadow before and after surgery. The width and narrowness of the bilateral zygomatic temporal suture between the control group and the experimental group were observed histologically, as well as whether the osteogenic activity of the two sides of the bone margin was similar, the degree of density of collagen fibers, and whether the bone marrow cavity near the edge of the suture had osteogenic activity

X-ray examination. The two groups of beagles were subject to positioning head X-rays at the radiology department of the first affiliated hospital of PLA general hospital before and after traction. X-ray machine no. : $6000 \mathrm{GE}$ definium, exposure conditions including $70 \mathrm{kv}, 1.5 \mathrm{mAS}$, the projection distance of $0.7 \mathrm{~m}$, The center of the ball tube of the X-ray machine is $1 \mathrm{~cm}$ below the zygomatic arch. The instrument has a grating perpendicular to the epicanthus of the beagle. It was then transferred to the processor GE CRSP1001 for analysis and measurement (accuracy $0.1 \mathrm{~mm}$ ), the image magnification is negligible.

Head shadow measurement was carried out by referring to the fixed points and related items of Coben (1971). Since it was difficult to determine the sella point of the dog, changes in the Angle of the skull base were measured with the optic nerve foramen as the center during the experiment. The skull base Angle is the intersection of the line between the optic foramen (OF) and the occipital base (Ba) and the palatal plane tangent (PL), representing the relationship between the development direction of the middle face and the skull base (Fig. 2).

Making tissue specimens. On the 15th day of traction, the effective specimen area was taken after execution, including zygomatic temporal suture and adjacent bone, immediately fixed with $10 \%$ neutral formaldehyde for $48 \mathrm{~h}$ and sealed. The fixed sample was placed into EDTA for decalcification. The standard of decalcification was that the pin could penetrate the sample smoothly, then dehydrated with gradient ethanol, paraffin embedded and sliced. Each specimen was cut into $4 \mathrm{~mm}$ thick paraffin sections, baked at 60 for $1 \mathrm{~h}$, dewaxed with xylene, dehydrated with gradient ethanol, stained with hematoxylin after washing, differentiated with $1 \%$ hydrochloric acid ethanol, returned to blue with lithium carbonate, stained with eosin, dehydrated with ethanol, dried in a drying oven and sealed. The width of bone seam, the morphology and structure of cells and new bone tissue were observed under the microscope, and the width of bone seam and the thickness of bone trabecula were measured.
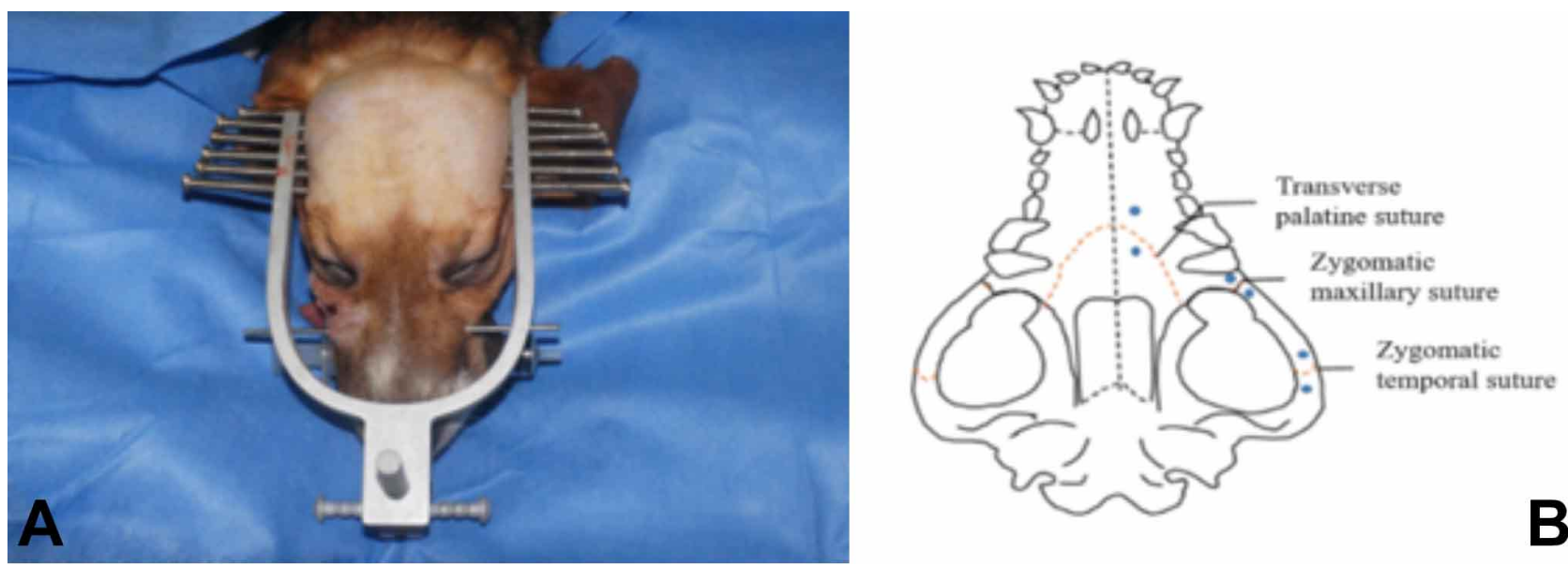

Fig. 1. A. Installation of external cranial. B. Bone markers before and traction frame was completed after each suture. 
Statistical analysis. Statistical analyses were performed using the Statistical Package for Social Science software version 22.0 (SPSS Inc., Chicago, IL). The difference between the mark points of bone seam before and after

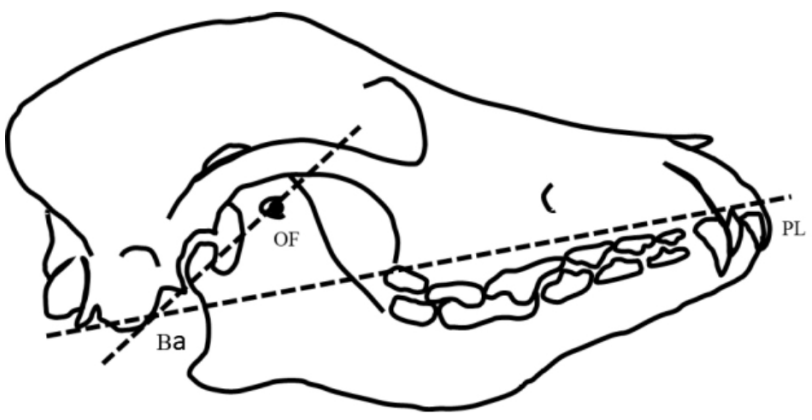

Fig. 2. Measurement of skull base Angle. Ba:occipital base point, OF:optic foramen, PL:palate plane.
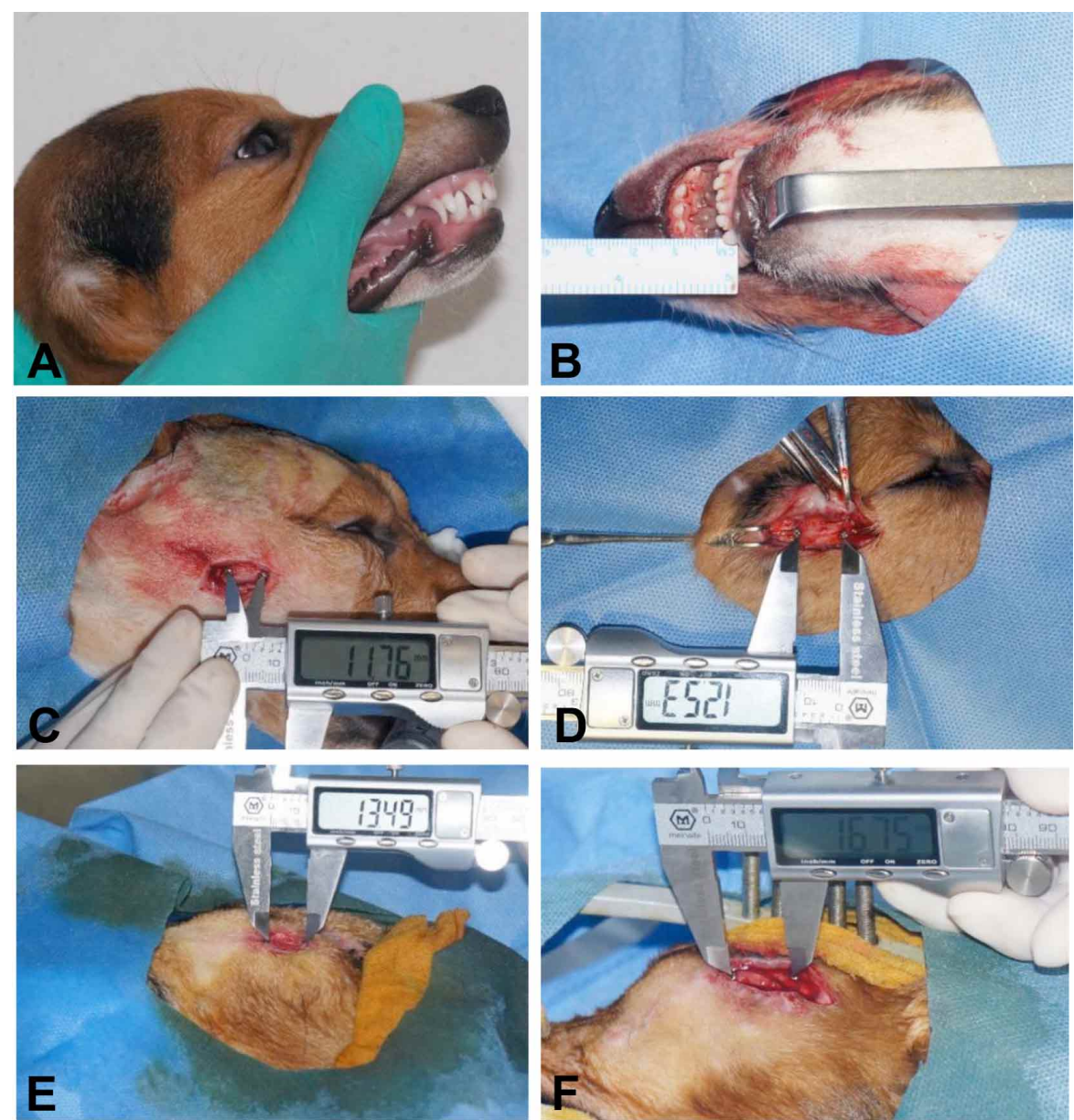

Fig. 2.1. A. Normal alignment before traction. B.Traction complete type of malocclusion. C. Traction distance of anterior D. The zygomatic temporal suture zygomatic temporal suture in control group distance after traction in the control group. E. Traction distance of anterior. F. Zygomatic temporal suture. Zygomatic temporal suture in experimental dog distance after traction in experimental dog. traction, skull base angle measured after traction and bone histometrology were compared by descriptive statistical analysis and t-test between two independent samples. The data were expressed by $\mathrm{c} \pm \mathrm{s}$, and the level of statistical significance was defined at $P<0.05$.

\section{RESULTS}

General observation. The two dogs in the experimental group regained consciousness within $3 \mathrm{~h}$ after surgery. Due to the interference of the traction frame, it was difficult to eat 3 to 5 days after the operation, and artificial assistance was needed. The beagle dogs in each group were in good living conditions during the scheduled observation period. The traction frame interfered the feeding of the puppies and had no other adverse effects on the puppies' daily life. All traction frames in each group were in good retention without loosening or falling off. Traction process did not change significantly after 2 3 days, then the maxillaries of $\operatorname{dog} \mathrm{s}$ protruded in the process of traction gradually and the occlusal relationship changed to type II malocclusion. At day 15 of traction, the coverage distance was about $8 \sim 9 \mathrm{~mm}$ (Fig. 2A and B). The Vernier caliper was used to measure the distance between the suture markers before and after traction. It was shown that the palatine transverse suture had the largest expansion (experimental group: $5.52 \pm 0.19 \mathrm{~mm}$, control group $1.31 \pm 0.06 \mathrm{~mm}, P<0.05)$, followed by the bilateral zygomatic temporal suture (experimental group, $3.12 \pm 0.15 \mathrm{~mm}$, control group $0.73 \pm 0.04 \mathrm{~mm}, P<0.05$ ), and the zygomandibular maxillary suture had the least expansion (experimentalgroup: $2.60 \pm 0.34$ $\mathrm{mm}$, control group $0.53 \pm 0.05 \mathrm{~mm}$, $P<0.05)$ (Figs. 2C to F, Table I).

Comparison of skull X-ray before and after traction of X-ray film. The differences between the suture implants in the experimental group were significantly larger than 
Table I. Measurement of the difference between bone suture implant nails with Vernier caliper before and after traction $(\mathrm{x} \pm \mathrm{s}, \mathrm{mm})$.

\begin{tabular}{lccc}
\hline Group & $\begin{array}{c}\text { Difference of zy gomatic } \\
\text { temporal suture }\end{array}$ & $\begin{array}{c}\text { Difference of zygomatic } \\
\text { and maxillary suture }\end{array}$ & $\begin{array}{c}\text { Difference of } \\
\text { palatine transverse suture }\end{array}$ \\
\hline control group & $0.73 \pm 0.04$ & $0.53 \pm 0.05$ & $1.31 \pm 0.06$ \\
experimental group & $3.12 \pm 0.15^{*}$ & $2.60 \pm 0.34^{*}$ & $5.52 \pm 0.19^{*}$ \\
\hline
\end{tabular}

those in the control group. It was shown that the palatine transverse suture had the largest expansion, followed by the bilateral zygomatic temporal suture, and the zygomandibular maxillary suture had the least expansion (Figs. 3A and B, Table II).

The measurement of skull base angle showed that: After 15 days of traction, the cranial basal angle of beagle dogs in the experimental group was $33.2 \pm 1.1$ and that the control group was $32.3 \pm 1.3$; there is no statistical difference $(P>0.05)$. After traction, there was no significant change in the skull base angle between the control group and the experimental group (Table III).

Histological observation. In the control group, the zygomatic temporal suture was relatively uniform in width, with similar osteogenic activity on both sides of the bone margin, dense collagen fibers, and osteoblasts are seen in the bone marrow cavity and near the suture margin, showing osteogenic activity (Fig. 4A).

The zygomatic temporal suture in the experimental group was widened (experimental group: $1209.388 \pm 42.714$ $\mu \mathrm{m}$, control group $248.276 \pm 22.864 \mu \mathrm{m}, P<0.05$ ), the number of fibroblasts increased significantly, the collagen fibers were loose, and the alignment direction of cells and fibers was basically the same, which was parallel to the direction of traction. Connective tissue of bone seam contains a large number of fibroblasts, with more small blood vessels and marrow cavities. Osteoid is composed of immature bone trabeculae. The bone trabeculae around the bone seam are thinner (experimental group: $23.684 \pm 3.774 \mathrm{~mm}$, control group: $86.810 \pm 9.219 \mathrm{~mm}, P<0.05$ ), the surface of new bone trabeculae and marrow cavity showed a large number of dense osteoblasts, which showed active osteogenesis (Fig. 4B, Table IV).

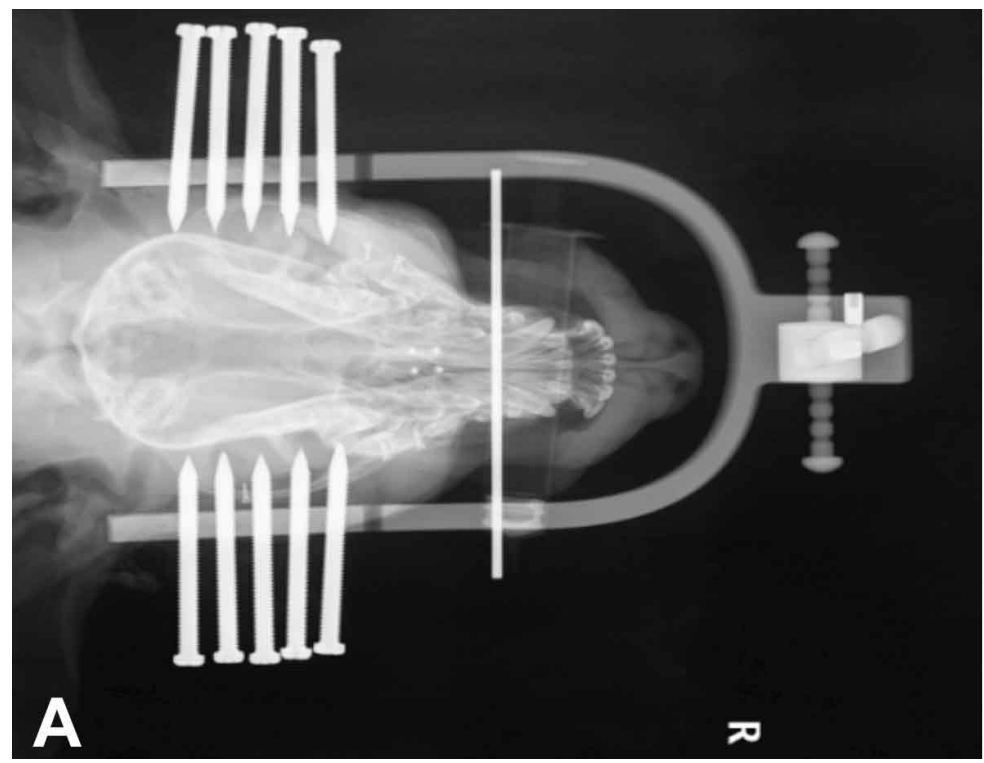

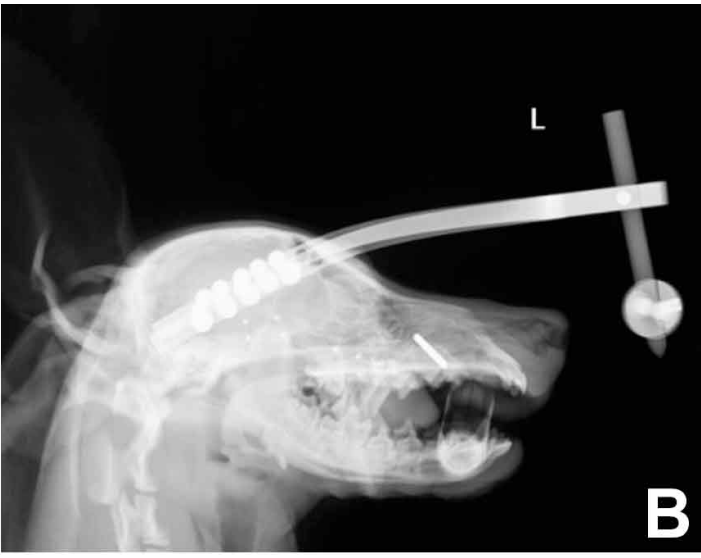

Fig. 3. A. Immediate cranial crown chin. B. Immediate cranial lateral film mounted on mounted on traction frame traction frame.

Table II. Measurement of the difference between bone suture implant nails with X-ray before and after traction $(\mathrm{x} \pm \mathrm{s}, \mathrm{mm})$.

\begin{tabular}{lccc}
\hline group & $\begin{array}{c}\text { Difference of zygomatic temporal } \\
\text { suture }\end{array}$ & $\begin{array}{c}\text { Difference of } \\
\text { zygomatic and maxillary suture }\end{array}$ & $\begin{array}{c}\text { Difference of } \\
\text { palatal transverse suture }\end{array}$ \\
\hline The control group & $0.07 \pm 0.01$ & $0.03 \pm 0.01$ & $0.12 \pm 0.01$ \\
Experimental group & $0.28 \pm 0.01 *$ & $0.20 \pm 0.02 *$ & $0.54 \pm 0.01 *$ \\
\hline
\end{tabular}




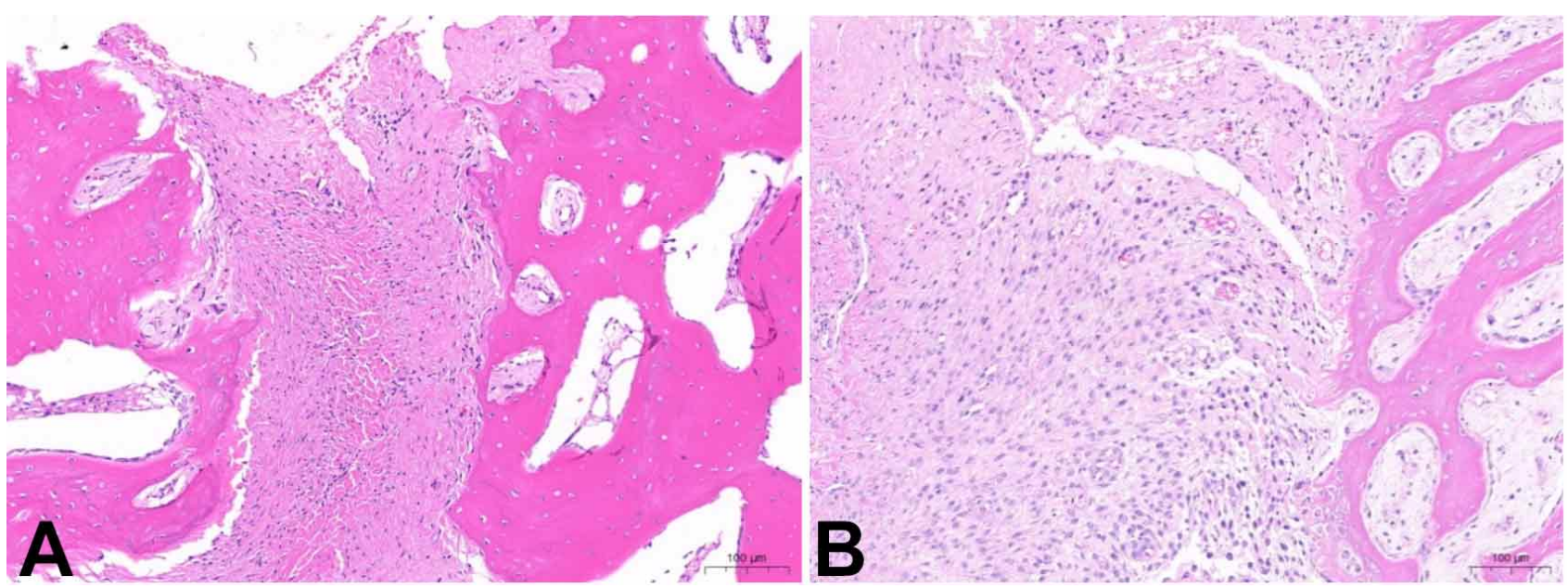

Fig. 4. A. Zygomatic temporal suture in control group HE¥100 (bar=100 micron). B. Zygomatic temporal suture in the experimental group $\mathrm{HE} \times 100$.

Table III. Changes of cranial basal angle ( $\mathrm{x} \pm \mathrm{s}, \mathrm{mm})$.

\begin{tabular}{lcc}
\hline Group & Before traction & After traction \\
\hline Control group & $32.5 \pm 1.1$ & $32.3 \pm 1.3$ \\
Experimental group & $32.6 \pm 1.2$ & $33.2 \pm 1.1$ \\
\hline
\end{tabular}

Table IV. Histometric measurement of zygomatic temporal suture after traction (x $\pm \mathrm{s}, \mathrm{mm})$

\begin{tabular}{lcc}
\hline Group & Bone suture width & Trabecular thickness \\
\hline Control group & $248.276 \pm 22.864$ & $86.810 \pm 9.219$ \\
Experimental group & $1209.388 \pm 42.714^{*}$ & $23.684 \pm 3.774 *$ \\
\hline
\end{tabular}

Note: * means that there is statistical difference $(P<0.05)$.

\section{DISCUSSION}

Selection of experimental animals for trans-sutural distraction technology. Since the 1960s and 1970s, traction osteogenesis was first used to reverse or forward the maxilla to correct edentulous and maxillary deformities, followed by reports of suture traction to correct cranial and maxillofacial deformities (Liu et al., 2005; Tong et al.). In the experimental research of trans-sutural distraction, pig, rat, goat and other animals are mostly used to establish research models (Liu et al., 2008; Savoldi et al., 2018). Hou et al. (2003) established a dog model and conducted a research experiment of mid-facial bone traction forward movement. The degree of similarity between dog and human joints was relatively high, but the traction effect of anterior jaw joint in the experiment could not simulate the traction effect of human joints well, and the traction device used in the experiment was quite different from that in clinical practice. Therefore, in this study, beagle dog was used as an animal model to study the trans-sutural distraction for the first time. Beagle dogs belong to small dogs with uniform body size, gentle personality and easy to raise. Because beagles are closer to human faces, they have become the most commonly used and standard animal types in experimental studies. The beagle is almost fully developed at nine months and about 7 to 8 years old at 16 weeks. Based on the above theories, a model of mid-face seam traction osteogenesis of beagle dog was established to better simulate the osteogenesis of mid-face seam traction of human and explore its development rule.
Characteristics of traction device. Most clinical transsutural distraction techniques use RED external traction frame made of titanium alloy, with a weight of about $300 \mathrm{~g}$ and a high cost, which is generally not used in animal experiments. After many experiments on material properties, we finally chose aluminum alloy as the head ring of traction frame within the reasonable cost range. Aluminum alloy has been widely used by the characteristics of light weight, low melting point, low density, good mechanical properties, corrosion resistance, low cost, easy processing and casting (Leszczynska-Madej \& Richert, 2010). Our self-designed aluminum alloy external fixed traction frame is light and stable, weighing about $150 \mathrm{~g}$, and the tensile strength is enhanced in the u-shaped area, which can be personalized design. During the experimental traction, the performance of the external fixed traction frame is stable and invisible. Due to the simple design, stable performance and low cost, the external head traction frame in this experiment is expected to be widely used.

Resistance center and bone penetration bearing mode. Hata et al. (1987) found that during the traction movement 
of the mid-face maxilla, the relationship between the direction of traction, namely the traction vector, and the resistance center of the maxilla was closely related to the rotation of the maxilla. When the traction direction was close to, or consistent with the direction of the resistance center, the rotation Angle of the maxilla during the traction movement was smaller. By building maxillary complex three-dimensional finite element model, Hou et al. (2009) found that the craniofacial complex can be effectively distracted anteriorly, when the downward force is applied to the floor of aperture piriforms in direction of 20-30 degrees to the occlusal plane. When the nose floor is used as the bearing force to pull the maxilla forward, the traction vector is basically consistent with the resistance center of the maxilla, which can reduce the rotation of the maxilla and realize the overall forward movement of the maxilla.

Jaw traction can be divided into tooth bearing point and bone bearing point according to different bearing positions. The tooth bearing point is to fix the traction device on the tooth, while the bone bearing point is to fix the traction device on the jaw bone through the fixation nail or implant. Several studies have proved that the bearing point of teeth is more likely to cause the rotation of jaw than that of bone during the traction of jaw (Kasai, 1998). Pellerin et al. (2001) reported in the trans-sutural distraction experiment that bone penetration can achieve better clinical effects. Although external retractor can cause scar left on the face, it has the advantage of small trauma, short operation time and drawing direction close to the resistance center, so it is suitable for the treatment of midfacial hypoplasia.

In this experiment, Kirschner wire was used to penetrate the bottom plane of the piriform hole of the maxilla, and the rear was about the position of the alveolar cavity, so that the traction vector could be as close as possible to the resistance center, and the maxillary rotation could be avoided largely. The direction of maxillary can be indicated by measuring the Angle of the skull base of the experimental group and control group before and after traction. The measurement of skull base Angle showed that: after 15 days of traction, the cranial basal angle of beagle dogs in the experimental group was $33.2 \pm 1.1$ and that of the control group was $32.3 \pm 1.3$, which indicates no statistical difference $(P>$ 0.05). The changes of the skull base Angle of the control group and the experimental group were not significant. It shows that the traction direction of the experimental group is basically the same as the growth direction of the control group, and the maxilla basically moves forward in parallel.

Traction effect. Midfacial with special joint structure, rich in blood vessels, due to the strong osteogenesis of osteoblasts in the suture, the fiber connection is easy to form. Therefore, the forward force applied by the suture traction in the midfacial of young dogs can make the suture expand and separate and form new bone under the stress, thus achieving the effect of the maxillary complex moving forward (Nanda \& Hickory, 1984).

In trans-sutural distraction experiments, to judge the position relationship of the upper and lower jaws, the coverage distance of the anterior mandibular teeth was mainly used. However, due to the force generated by the traction frame acting on the whole skull and bone seam, the maxillary is not simply moved forward, and the lower jaw will also move due to growth and development. Therefore, it is not accurate to use the coverage distance of mandibular anterior teeth as the standard to evaluate the movement speed of the maxillary complex. Therefore, we measured the absolute rate of maxillary progression by measuring the distance to the suture associated with the maxillary complex. The orthotic force used in this experiment is similar to the traction value of SDO technology clinically, and the traction speed is about $0.54 \sim 0.62 \mathrm{~mm} / \mathrm{d}$. Since elastic traction is a continuous force, which is more in line with physiological characteristics, elastic traction is adopted in this experiment.

In the experimental results, both Vernier caliper and $\mathrm{X}$-ray measurement results showed that the difference between the implant screws in the experimental group was significantly larger than that in the control group before and after traction. In the experimental group, the difference between different suture implant nails showed that the distance between the marked points of the palatal transverse suture was the largest. It was shown that the palatine transverse suture had the largest expansion, followed by the bilateral zygomatic temporal suture, and the zygomandibular maxillary suture had the least expansion. The largest expansion of the palatine transverse suture may be because it is proximity to the resistance center. The zygomatic temporal suture is farther away from the resistance center than the zygomandibular maxillary suture, but the expansion is larger, which may be related to the anatomical structures of the two. It is shown that in the control group, the sutures were relatively uniform in width, with similar osteogenic activity on both sides of the bone margin, dense collagen fibers, and osteoblasts are seen in the bone marrow cavity at and near the suture margin, showing osteogenic activity. The sutures widened in the experimental group, the number of fibroblasts increased significantly, the collagen fibers were loose, and the alignment direction of cells and fibers was basically the same, which was parallel to the direction of traction. Connective tissue of bone seam contains a large number of fibroblasts with more small blood vessels and marrow cavities. Osteoid is composed of immature bone trabeculae. The bone trabeculae around the bone seam are 
thinner, the surface of new bone trabeculae and marrow cavity showed a large number of dense osteoblasts, which showed active osteogenesis.

Growing Beagle dogs can be used to establish an animal model of suture traction for experimental study. The traction of the cranial traction frame designed by ourselves in this experiment can be applied to the follow-up experiment. In the experiment, Kirschners penetrated the base plane of the pyriform hole of the maxilla (the posterior part of the canine fossa), and the traction force and the center of resistance are similar. The traction direction is basically the same as the growth direction, and the maxilla is basically parallel to the front.

ZHANG, B. B.; HAN, R.; LIU, Y. K.; GAO, Q. W. \& LI, B. Cambios morfológicos en la cara media de perros Beagle tratados por distracción trans-sutural. Int. J. Morphol., 38(4):947-955, 2020.

RESUMEN: La distracción trans-sutural es un proceso biológico que induce la formación de hueso nuevo y cambia la posición del éste al tirar de la sutura en crecimiento bajo la acción de fuerzas externas. Actualmente, se ha aplicado la terapia para la hipoplasia de la cara media tratada por distracción trans-sutural. En este estudio, fueron seleccionados perros Beagle como animales experimentales, y un dispositivo de tracción fue instalado a los perros para simular el proceso de tratamiento de la distracción trans-sutural en el rostro humano. El objetivo fue proporcionar una base para la investigación posterior sobre mecanismos relacionados con la distracción trans-sutural. El modelo animal puede proporcionar la base para este tipo de estudio de seguimiento de la distracción trans-sutural. Perros Beagle de 45 meses de edad se dividieron aleatoriamente en dos grupos: 3 en el grupo experimental y 3 en el grupo control. Los clavos de implante se usaron como marcadores óseos en la sutura temporal cigomática bilateral, la sutura maxilar cigomandibular y en la sutura transversal palatina en el grupo experimental. La tracción del maxilar se realizó mediante el marco de tracción craneal externo con fosa canina como punto de apoyo, $800 \mathrm{~g}$ de fuerza a cada lado, tracción elástica durante 15 días. En el grupo control solo se implantó el clavo del implante como marcador óseo en ambos lados de la sutura. La distancia entre dos clavos de implante se midió mediante calibradores de vernier y examen de rayos $\mathrm{X}$, en comparación con los cambios preoperatorios y postoperatorios. Se utilizaron mediciones cefalométricas y de rayos X para medir el cambio en el ángulo basal craneal. La tinción con HE se usó para observar el ancho de las suturas óseas, la morfología y la estructura de las células y el tejido del hueso nuevo bajo el microscopio de contraste de fase. Luego se realizó un análisis estadístico descriptivo y una prueba $t$ entre dos muestras independientes para los datos de medición. El grupo experimental tuvo una buena retención del cuadro de tracción del Beagle. En el grupo experimental, los maxilares de los perros sobresalieron gradualmente en el proceso de tracción y la relación oclusal cambió a maloclusión tipo II. Cuando la tracción era de 15 días, la distancia de cobertura fue de aproximadamente $8 \sim 9 \mathrm{~mm}$. Antes y después de la tracción, la distancia entre los puntos de referencia indicaba que el espacio entre la sutura palatina transversal era más grande (grupo experimental: 5,52 $\pm 0,19 \mathrm{~mm}$, grupo de control 1,31 $\pm 0,06 \mathrm{~mm}, P<0,05)$, y la sutura cigomáticotemporal fue la segunda. (Grupo experimental: 3,12 \pm $0,15 \mathrm{~mm}$, grupo control $0,73 \pm 0,04 \mathrm{~mm}, P<0,05)$, y la sutura cigomaticomaxilar fue menor (grupo experimental, 2,60 $\pm 0,34$ $\mathrm{mm}$, grupo control $0,53 \pm 0,05 \mathrm{~mm}, P<0,05)$. El ángulo basal craneal no cambió antes ni después de la operación (grupo control $32,3 \pm 1,3$, grupo experimental, 33,2 $\left.\pm 1,1^{\circ}, P>0,05\right)$. La histología mostró que las fibras colágenas en la sutura del grupo control eran más densas y los osteoblastos se observaron en el margen de la sutura, mostrando actividad osteogénica. En el grupo experimental se amplió significativamente la sutura (1209,388 $\pm 42,714 \mu \mathrm{m}$, grupo control 248,276 $\pm 22,864 \mu \mathrm{m}, P<0,05$ ), el número de fibroblastos aumentó significativamente con fibras colágenas dispersas. La dirección de la disposición de la celda y las fibras era paralela a la fuerza de tracción. Se observó gran cantidad de vasos sanguíneos pequeños, cavidades medulares, y trabéculas óseas alrededor de la sutura ósea (grupo experimental: 23,684 $\pm 3,774 \mathrm{~mm}$, grupo control: 86,810 $\pm 9,219 \mathrm{~mm}, P<0,05$ ), que mostró actividad osteogénica activa. El perro Beagle en crecimiento se puede utilizar para estudios experimentales y así establecer un modelo animal de tracción de sutura. En el proceso, se usó alambre de Kirschner para penetrar en el plano inferior del foramen piriforme del maxilar (aproximadamente en la posición de la fosa canina en la parte posterior) y la dirección de tracción fue básicamente la misma que en el crecimiento.

PALABRAS CLAVE: Diabetes de sutura osteogénesis; Cuadro de tracción extracraneal; Hipoplasia de la cara media; Modelo animal.

\section{REFERENCES}

Coben, S. E. The biology of Class II treatment. Am. J. Orthod., 59(5):47087, 1971.

Garib, D.; Yatabe, M.; de Souza Faco, R. A.; Gregório, L.; Cevidanes, L. \& de Clerck, H. Bone-anchored maxillary protraction in a patient with complete cleft lip and palate: A case report. Am. J. Orthod. Dentofacial Orthop., 153(2):290-7, 2018.

Hata, S.; Itoh, T.; Nakagawa, M.; Kamogashira, K.; Ichikawa, K.; Matsumoto, M. \& Chaconas, S. J. Biomechanical effects of maxillary protraction on the craniofacial complex. Am. J. Orthod. Dentofacial Orthop., 91(4):305-11, 1987.

Hou, M.; Liu, C. M.; Liang, L. M.; Ma, X. \& Sony, R. Y. The possibility of midface skeleton protraction: an experimental study in dogs. Zhonghua Zheng Xing Wai Ke Za Zhi, 19(5):360-3, 2003.

Hou, M.; Liu, C. M.; Zhang, H. Z.; Liang, L. M. \& Gao, Q. W. Threedimensional finite element analysis for different directions distraction at midface. Zhonghua Zheng Xing Wai Ke Za Zhi, 25(2):117-9, 2009.

Kasai, K. Soft tissue adaptability to hard tissues in facial profiles. Am. J. Orthod. Dentofacial Orthop., 113(6):674-84, 1998.

Leszczynska-Madej, B. \& Richert, M. The effect of strain rate on the evolution of microstructure in aluminium alloys. J. Microsc., 237(3):399-403, 2010.

Lin, Y.; Fu, Z.; Ma, L. \& Li, W. Cone-beam computed tomographysynthesized cephalometric study of operated unilateral cleft lip and palate and noncleft children with Class III skeletal relationship. Am. J. Orthod. Dentofacial Orthop., 150(5):802-10, 2016. 
Liu, C.; Hou, M.; Liang, L.; Huang, X.; Zhang, T.; Zhang, H.; Ma, X. \& Song, R. Sutural distraction osteogenesis (SDO) versus osteotomy distraction osteogenesis (ODO) for midfacial advancement: a new technique and primary clinical report. J. Craniofac. Surg., 16(4):53748, 2005.

Liu, R. K.; Zhang, Q. F.; Ma, X. Q.; Cheng, M. \& Zou, S. J. Temporospatial expression of bFGF and IGF-I in growing goats with cranial suture distraction osteogenesis. Sichuan Da Хие Хие Baо Yi Хие Ban, 39(4):605-8, 2008.

Marulanda, J. \& Murshed, M. Role of Matrix Gla protein in midface development: Recent advances. Oral Dis., 24(1-2):78-83, 2018.

Meazzini, M. C.; Zappia, L. B.; Tortora, C.; Autelitano, L. \& Tintinelli, R. Short- and long-term effects of late maxillary advancement with the Liou-Alt-RAMEC protocol in unilateral cleft lip and palate. Cleft Palate Craniofac. J., 56(2):159-67, 2019.

Nanda, R. \& Hickory, W. Zygomaticomaxillary suture adaptations incident to anteriorly-directed forces in rhesus monkeys. Angle Orthod., 54(3):199-210, 1984.

Pellerin, P.; Capon-Desgardin, N.; Martinot-Duquennoy, V.; Vinchon, M. $\&$ Dhellemmes, P. Mid-facial distraction without osteotomy with a transfacial pin. Report of 4 clinical cases. Ann. Chir. Plast. Esthet., 46(4):27784, 2001.

Savoldi, F.; Xu, B.; Tsoi, J. K. H.; Paganelli, C. \& Matinlinna, J. P. Anatomical and mechanical properties of swine midpalatal suture in the premaxillary, maxillary, and palatine region. Sci. Rep., 8(1):7073, 2018.

Scolozzi, P. Distraction osteogenesis in the management of severe maxillary hypoplasia in cleft lip and palate patients. J. Craniofac. Surg., 19(5):1199-214, 2008.

Tong, H.; Gao, F.; Yin, J.; Shi, Z.; Song, T.; Li, H.; Sun, X.; Wang, Y.; Yin, N. \& Zhao, Z. Three-dimensional quantitative evaluation of midfacial skeletal changes after trans-sutural distraction osteogenesis for midfacial hypoplasia in growing patients with cleft lip and palate. $J$. Craniomaxillofac. Surg., 43(9):1749-57, 2015.

Yatabe, M.; Garib, D. G.; Faco, R. A. S.; de Clerck, H.; Janson, G.; Nguyen, T.; Cevidanes, L. H. S. \& Ruellas, A. C. Bone-anchored maxillary protraction therapy in patients with unilateral complete cleft lip and palate: 3-dimensional assessment of maxillary effects. Am. J. Orthod. Dentofacial Orthop., 152(3):327-35, 2017.

\author{
Corresponding author: \\ Bing Li \\ Stomatology Hospital \\ Shanxi Medical University \\ 63 XinjianRoad \\ Taiyuan 030001 \\ CHINA
}

Email: libing-1975@163.com

\author{
Quan-Wen Gao \\ Department of Burns and Plastic Surgery \\ First Hospital Affiliated to General Hospital of PL \\ Beijing \\ CHINA
}

Email: gaoqw2000@126.com

Received: 20-12-2019

Accepted: 10-02-2020 